\title{
PRODUCTION OF ANTIMICROBIAL AGENTS FROM SOME BACILLUS ISOLATES
}

\author{
Laila R.A., Salem A. Mahfouz and Yasser M. H. Abd- El-Karem \\ Agricultural Microbiology Department, Faculty of Agriculture, Fayoum University.
}

\begin{abstract}
A survey was undertaken for bacterial isolates capable of producing antimicrobial agents from different Egyptian soils .These isolates were tested against various species of microorganisms $(\mathrm{G}+, \mathrm{G}-$, spore formers , yeast and fungi) using inhibition zone determination technique and standard disks of antibiotics as reference.

One or more of the pathogenic bacterial strains used as tested organisms were affected by antimicrobial substances produced by bacterial isolates as indicated by inhibition zones formation. The effect of antimicrobial substances produced by bacterial isolates were compared with the effect of 11 antibiotic disks as reference. The most effective isolates against the tested organisms were identified by API $50 \mathrm{CHB}$ system which indicate that these isolates were Bacillus licheniformis, Bacillus amyloliquefaciens, and Bacillus subtilis.

Whole sediment produced by the five bacterial strains were found to be safe when using as ration for albino rats.
\end{abstract}

Key words: Antimicrobial-Isolation and Identification - Biological assay experiment - Bacillus.

\section{INTRODUCTION}

A few decades after the introduction of antibiotics into clinical practice, resistance by pathogenic bacteria has become a major health concern. Indeed, while in the mid1970s infectious diseases were considered virtually conquered (Breithaupt, 1999), many Gram positive and Gram negative bacteria opportunistic pathogens were becoming resistant to virtually every clinically available drug (Greenberg, 2003).

In recent years, biological control of plant pathogens is considered as a potential control strategy as chemical control became undesirable. At present, effective management of plant diseases and microbial contamination in several agricultural commodities is generally achieved using synthetic pesticides. However, the continual and indiscriminate application of these chemical fungicides has caused health hazards in animals and human due to residual toxicity (Alemu, 2014).

Quite a large number of microorganisms have the capacity of producing bio-agents that can be used as antibiotics. From Streptomyces, Ceylan et al., (2008) evaluated their inhibitory activities on seven microorganisms including multiple antibiotic resistant Staph. aureus and Stenotrophomonas maltophilia.

Fayoum J. Agric. Res. \& Dev., Vol. 30, No.1, January, 2016 
Ogunmwonyi (2010) isolated ten putative Streptomyces strains and assessed them for antibiotic production and activity against a wide range of bacteria. Also, Aparanji et al., (2013) collected six isolates of Actinomycetes from marine sediments in India. Among these six isolates, only one showed potent activity against all the bacteria and fungi tested.

Kawaguchi et al., (2013) reported that among 151fungal isolates, 26 strains were found to reproduce anti- $C$. albicans activity in liquid medium.

Liasi et al., (2009) found that three isolates of lactic acid bacteria (LAB) from the fermented food product identified as genus Lactobacillus ( $L$. casei LA17, L. plantarum LA22 and L. paracasei LA02), the antibacterial agent produced by the isolates inhibited the growth of a range of gram-positive and gram-negative microorganisms.

Sixteen soil samples were collected by ( Kuta et al., 2009) analyzed some soil samples for the presence of Bacillus spp. Antibiotic production tests indicated that nine Bacillus species out of twelve isolated could be used to produce antibiotics that had effect on the test organisms. However, Paenibacillus polymyxa, B. sphaericus and B. laterosporous had little or no effect on the tested organisms.

Sarker et al., (2010) found that the gram-positive bacterium $B$. subtilis produces a large number of antibiotics, which are classified as ribosomal or nonribosomal. Moshafi et al., (2011) screened a variety of microorganisms from environmental soil samples for antibiotics production. Bacterial isolates were found to have antibacterial and antifungal activity on the standard indicator species. Tabbene et al., (2011) found that B. subtilis B38, isolated from soil showed antimicrobial activity against human pathogenic $C$. albicans species. Specific PCR primers revealed the presence of the bam C gene, which is involved in the biosynthesis of bacillomycin D. Malnicheva et al., (2012) isolated bacterial strains with a high level of antimicrobial activity from soil and identified as $B$. megaterium. In submerged cultures, nine out of ten $B$. megaterium strains were found to produce antibacterial antibiotics differing in their spectra of action.

The aim of this investigation is an attempt to find antimicrobial principals naturally produced by some well-known bacteria which can replace the use of chemotherapeutic products.

\section{MATERIALS \& METHODS}

\section{Collection and preparation of soil samples:}

In systematic screening program for the isolation of some target bacteria, 30 soil samples were collected from different locations from upper layer where most of the microbial activity usually takes place and where most of the bacterial population is concentrated.

Isolation of antimicrobial agents producing bacteria:

Fayoum J. Agric. Res. \& Dev., Vol. 30, No.1, January, 2016 


\section{PRODUCTION OF ANTIMICROBIALNTS...............................}

Seventy isolates were obtained from soil samples by preparing serial dilutions from 10-1 to 10-10. The isolation of bacteria was made to whom which gave a clear zone of inhibition around their growth after 24 to 48 hours incubation period. The selection of the isolates was made only for those having a very wide zone of inhibition and those which never lost their potency when tested again in replicated inoculation, and those which were active, principally , against Bacillus spp.

\section{Test microorganisms:}

Sum of eleven different kinds of identified microorganisms were used in this study. Two G- bacteria (E. coli ATCC 25922 and Salmonella typhimurium , four G+ bacteria (Listeria monocytogenes ATCC 15313, B. cereus ATCC 13753, Micrococcus luteus, and Staphylococcus aureus ATCC 8095), Human pathogenic yeast Candida albicans, and fungi Penicilium roquefortii, Aspeagillus niger, Fusarium semitectum, and Alternaria alternata were used as test microorganisms for the detection of the antimicrobial activity. These strains were chosen because they have important sanitary position for human, animals and plants.

Antibiotics:

Eleven well known antibiotics were used in vitro diagnosis as reference to be compared in their action on different tested organisms with that of the isolated bacteria from soils. Claforan, Nebcin , Garamycin, Unacin , Tarivid, Rociphin , Fucidin , Cefobid, Lincocin , Velosef and Keflex . These eleven antibiotics were chosen because they were already used in medicinal treatments against a wide variety of diseases whether for human, animals, and plants . Nearly all had broadcast effects.

\section{Antimicrobial activity assay}

\section{A- Disc diffusion assay for bacteria :}

Luria-Bertani agar plates were inoculated with $1 \%$ tested organism, left to dry then antibiotic containing discs were applied. The plates were incubated for $24 \mathrm{hrs}$ at the optimum temperature for each bacterial strain. The antibacterial activities of antibiotics were assessed by measuring the zone of inhibition ( $\mathrm{mm}$ ) against the tested bacteria (Kumar et al 2012).

\section{B- $\quad$ Disc diffusion assay for fungi :}

Potato dextrose agar medium was used for determination of the antifungal effect of Bacillus isolates. The $\mathrm{pH}$ of the medium was adjusted to $5.6 \pm 0.2$ then autoclaved at $121^{\circ} \mathrm{C}$ for $15 \mathrm{~min}$. Then constant number of spores of different fungi were added to $20 \mathrm{ml}$ of medium and poured in Petri dishes and let for drying and then the disks of Bacillus isolates containing known amount of supernatant $(0.1 \mathrm{ml})$ were placed on the surface of agar and incubated for appropriate time. Clear zone around each disc were examined after two days of incubation (Farhana et al., 2011).

Identification of Bacillus isolates

Fayoum J. Agric. Res. \& Dev., Vol. 30, No.1, January, 2016 
Laila R.A., Salem A. Mahfouz and Yasser M. H. Abd-El-Karem

The carbohydrate fermentation patterns of the selected five Bacillus isolates were determined with API CHB50 fermentation strips in CHB medium as specified by the manufactures instruction. For API kit method, sufficient growth of each isolate being identified was inoculated into the suspension medium supplied with the API Bacillus kit so as to produce an inoculum density equivalent to a MacFarland 2 standard. Separate suspension for use with the API API $50 \mathrm{CHB}$, was prepared at a density equivalent to a MacFarland 2 standard. Using sterile Pasteur pipettes, approximately $1 \mathrm{ml}$ of the organism suspension was inoculated into each microtubule of the incubation tray. The API systems were inoculated in accordance with manufacturer's instructions. After inoculation, identification system was incubated at $30^{\circ} \mathrm{C}$ for 24-48 hrs and read after $24 \mathrm{hrs}$ incubation, with a final reading made after 48 hrs incubation. All results were recorded on the work sheets provided and interpreted using the API Web database systems. To identify an organism, the API web software compares the profiles obtained with the profiles of taxa (Aruwa and Olatope, 2015).

The 16S rRNA gene sequence has been determined for a large number of strains. Gen Bank, the largest databank of nucleotide sequences, has over 20 million deposited sequences, of which over 90,000 are of 16S rRNA gene. This means that there are many previously deposited sequences against which to compare the sequence of an unknown strain.

Lastly, the 16S rRNA gene is universal in bacteria, and so relationships can be measured among all bacteria. In general, the comparison of the $16 \mathrm{~S}$ rRNA gene sequences allows differentiation between organisms at the genus level across all major phyla of bacteria, in addition to classifying strains at multiple levels, including what we now call the species and subspecies level. The occasional exceptions to the usefulness of $16 \mathrm{~S}$ rRNA gene sequencing usually relate to more than one well-known species having the same or very similar sequences (Jill, 2004).

Media:

Luria Bertani agar medium (Atlas and Parks 1997)

Luria bertani agar medium was used to determine the antimicrobial effect of Bacillus isolates supernatant by disk diffusion method containing $(\mathrm{gm} / \mathrm{l}) ; 10.0 \mathrm{~g}$ $5.0 \mathrm{~g}$ Yeast extract, $15.0 \mathrm{~g} \quad$ Agar at $\mathrm{pH} 7.0 \pm 0.2$.

Tryptone, $10.0 \mathrm{~g} \mathrm{NaCl}$,

Potato dextrose agar medium (PDA), Atlas and Parks (1997) containing (gm/1); $200.0 \mathrm{~g}$ Potato infusion, 20.0g Dextrose and $15.0 \mathrm{~g}$ Agar at $\mathrm{pH} 4.5$ was used for fungal growth and test.

For feeding rats, a basal diet containing; Casein 15\%, Mineral salts $4 \%$, Vitamins $1 \%$, Corn oil 7\%, Sawdust 5\% and Starch $68 \%$.

Feeding experiment (biological assay):

Fayoum J. Agric. Res. \& Dev., Vol. 30, No.1, January, 2016 
PRODUCTION OF ANTIMICROBIALNTS..............................5

Thirty weanling albino rats with average weight of 110 to $149 \mathrm{gm}$, obtained from Agriculture Research Center were acclimated to animal house condition housed in metabolic cages $(30 \times 40 \times 35 \mathrm{~cm})$, for one week prior the experiment.

The rats were housed in groups of five each in universal polypropylene cages at room temperature. Cages were kept in well aerated place with continuous artificial aeration all over the experimental period. Albino rats were fed on normal basal diet incorporated with certain amounts of the sediment obtained from growing different Bacillus strains on the basal medium.

\section{Liver functions}

The concentration of serum glutamic pyruvic (GPT) and glutamic oxaloacetic (GOT) transaminase were calourimetrically determined using transaminase kite according to the method of Reitman and Frankel (1957) .

\section{Kidney functions}

Creatinine, bilirubin and urea were determined according to the methods described by (Gornall et al., 1948; Doumas et al., 1971; and Fawcett and Soctt, 1960) respectively.

\section{RESULTS AND DISCUSSION}

Isolates antagonism effect against the six tested bacteria and five tested fungi

Out of the 50 Bacillus isolates, the more effective five isolates, A6, A9, A13, A14 and A16 greatly inhibited E. coli, L. monocytogenes, B. cereus, S. typhimurium and Staph. aureus, respectively as shown in (table 1) were selected for further study.

When those five selected bacterial isolates were tested against some fungi and yeast they showed strong effect (Table 2).

\section{Antibiotics susceptibility of the selected five Bacillus isolates}

The five Bacillus strains were tested for their in vitro antibiotic susceptibility using disks of 11different reference antibiotics. The results obtained (Table 3) show the following: (i) all strains have showed a variable antibiotic resistance, (ii) all strains were resistant to Claforan, Cefobid, Fucidin. (iii) all strains were affected by Tarivid, Garamycin , and Nebcin (L.monocytogenes was not affected by Garamycin).

Table (1): The more inhibititive effect of potent isolates against different pathogenic bacteria

\begin{tabular}{|c|c|c|c|c|c|c|}
\hline \multirow{2}{*}{$\begin{array}{c}\text { Isolate } \\
\text { No. }\end{array}$} & \multicolumn{6}{|c|}{ Inhibition zone diameter ( mm) } \\
\cline { 2 - 7 } & $\begin{array}{c}\text { B. } \\
\text { cereus }\end{array}$ & $\begin{array}{c}\text { M. } \\
\text { luteus }\end{array}$ & $\begin{array}{c}\text { Staph. } \\
\text { aureus }\end{array}$ & $\begin{array}{c}\boldsymbol{E} \\
\text {.coli }\end{array}$ & $\begin{array}{c}\text { S } \\
\text {.typhimurium }\end{array}$ & $\begin{array}{c}\text { L } \\
\text { monocytogenes }\end{array}$ \\
\hline A6 & 20 & 28 & 29 & 25 & 20 & 20 \\
\hline A9 & 28 & 30 & 20 & 35 & 33 & 25 \\
\hline A13 & 28 & 31 & 30 & 40 & 40 & 30 \\
\hline A14 & 25 & 30 & 30 & 35 & 38 & 32 \\
\hline
\end{tabular}

Fayoum J. Agric. Res. \& Dev., Vol. 30, No.1, January, 2016 
Laila R.A., Salem A. Mahfouz and Yasser M. H. Abd-El-Karem 6

\begin{tabular}{|l|l|l|l|l|l|l|}
\hline A16 & 20 & 26 & 30 & 45 & 28 & 20 \\
\hline
\end{tabular}

- The diameter of the saturated disk was $9 \mathrm{~mm}$ - The medium used was nutrient broth. - Incubation period was $24 \mathrm{hrs}$ at $30^{\circ} \mathrm{C}$.

Fayoum J. Agric. Res. \& Dev., Vol. 30, No.1, January, 2016 
PRODUCTION OF ANTIMICROBIALNTS. .7

Table (2): Antagonism activity of the most effective five isolates against different fungal strains.

\begin{tabular}{|c|c|c|c|c|c|}
\hline & \multicolumn{5}{|c|}{ Inhibition zone diameter ( mm) : } \\
\hline $\begin{array}{c}\text { Isolate } \\
\text { No. }\end{array}$ & $\begin{array}{c}\boldsymbol{P} . \\
\text { roquefortii }\end{array}$ & $\begin{array}{c}\boldsymbol{A} . \\
\text { niger }\end{array}$ & $\begin{array}{c}\boldsymbol{F} . \\
\text { Semitectum }\end{array}$ & $\begin{array}{c}\boldsymbol{A} . \\
\text { alternata }\end{array}$ & $\begin{array}{c}\boldsymbol{C} \text {. } \\
\text { albicans }\end{array}$ \\
\hline A6 & 44 & 29 & 44 & 55 & 60 \\
\hline A9 & 31 & 25 & 56 & 35 & 38 \\
\hline A13 & 44 & 29 & 64 & 30 & 44 \\
\hline A14 & 54 & 44 & 42 & 40 & 45 \\
\hline A16 & 34 & 29 & 44 & 23 & 38 \\
\hline
\end{tabular}

- The diameter of the saturated disk was $9 \mathrm{~mm}$. - The medium used was nutrient broth.

- Incubation period was $24 \mathrm{hrs}$ at $30^{\circ} \mathrm{C}$.

Table (3): Comparison between antibacterial effects of some tested antibiotics and the Bacillus supernatants on the five tested bacteria:

\begin{tabular}{|c|c|c|c|c|c|c|}
\hline \multirow{2}{*}{$\begin{array}{c}\text { Antibiotics } \\
\text { disks }\end{array}$} & $\begin{array}{c}\text { Dose } \\
(\mu \mathrm{\mu g} / \text { disk })\end{array}$ & \multicolumn{5}{|c|}{$\begin{array}{c}\text { Inhibition zone diameter (mm) : } \\
\text { (antibiotics) }\end{array}$} \\
\cline { 3 - 7 } & & $\begin{array}{c}\text { Staph } \\
\text { cereus }\end{array}$ & $\begin{array}{c}\text { L. } \\
\text { aureus }\end{array}$ & $\begin{array}{c}\text { S. } \\
\text { monocytogenes }\end{array}$ & $\begin{array}{c}\text { E. } \\
\text { typhimurium } \\
\text { coli }\end{array}$ \\
\hline Keflex & 30 & N.E. & 15 & 6 & 25 & N.E. \\
\hline Velosef & 30 & 9 & N.E. & N.E. & 9 & N.E. \\
\hline Lincocin & 30 & 18 & 14 & 13 & 25 & N.E. \\
\hline Cefobid & 75 & N.E. & N.E. & N.E. & 18 & N.E. \\
\hline Fucidin & 10 & N.E. & N.E. & N.E. & N.E. & N.E. \\
\hline Rociphin & 30 & N.E. & 14 & 13 & 30 & 21 \\
\hline Unacin & 30 & 18 & 16 & 15 & 18 & N.E. \\
\hline Tarivid & 10 & 30 & 26 & 33 & 40 & 45 \\
\hline Gramycin & 10 & 25 & 15 & N.E. & 23 & 31 \\
\hline Nebcin & 10 & 25 & 14 & 19 & 20 & 25 \\
\hline Claforan & 30 & N.E. & N.E. & 9 & 12 & N.E. \\
\hline IsolateNo. & Dose & & $\begin{array}{c}\text { Inhibition zone diameter (mm) } \\
\text { (Bacillus isolates supernatants ) }\end{array}$ \\
\hline A.6 & 1 & 20 & 29 & 20 & 20 & 25 \\
\hline A.9 & 2 & 28 & 20 & 25 & 33 & 35 \\
\hline A.13 & 1 & 28 & 30 & 30 & 40 & 40 \\
\hline A.14 & 1 & 25 & 30 & 32 & 38 & 35 \\
\hline A.16 & 2 & 20 & 30 & 20 & 28 & 45 \\
\hline
\end{tabular}

- The diameter of the saturated disk was $9 \mathrm{~mm}$. - The diameter of the standard disk was $6 \mathrm{~mm}$. - The medium used is nutrient broth. N.E. = no effect

Fayoum J. Agric. Res. \& Dev., Vol. 30, No.1, January, 2016 
Note: all antibiotics were added at the recommended dose usually implicated .

\section{Identification of the five bacterial isolates using API 50 CHB kits:}

Identification of the efficient selected five isolates to species level was carried out on the basis of their carbohydrates fermentation patterns obtained by API 50 CHB kits. According to the API database correlation these isolates were identified as two isolates (97.5\%) B. subtilis, two isolates (99.9\%) B. amyloliquefaciens, and one isolate (98.2\%) B. licheniforms.

\section{Genotypic characterization of the selected two Bacillus isolates:}

The 16SrRNA gene sequences of isolates A6, and A13 were compared with sequences in the Gene-Bank database. A phylogenetic tree based on 16SrRNA sequences (Fig. 1) revealed affiliation of isolate A6 to the genus Bacillus, comprising $98 \%$ identity to B. sonorensis, which is most closely related to $B$. licheniformis . While revealed affiliation of isolate A13 to the genus Bacillus, comprising 99\% identity to B. methylotrophicus ; Comparative genomic analysis showed only minor differences between this strain and the genome of the B. amyloliquefaciens subsp.

The effect of feeding rats on the whole sediment produced by tested Bacillus strains:

At the end of the feed experiment all groups except group 6 showed a slight decrease in weight, while the same group showed a slight increase in weight (Table 4). There are no significant differences between groups in the measurement of urea and enzyme alanine aminotransferase (ALT). While some differences were found between the groups in measuring creatinine (in group 4 decreased creatinine value while in group 5 it increased but other groups showed no significant differences). Enzyme aspartate aminotransferase (in group 2 was decreased while increased in group 4, 5 but other groups showed no significant differences (Table 5).

Fayoum J. Agric. Res. \& Dev., Vol. 30, No.1, January, 2016 
PRODUCTION OF ANTIMICROBIALNTS.............................9

Fayoum J. Agric. Res. \& Dev., Vol. 30, No.1, January, 2016 
As to blood picture, five groups showed an increase in hemoglobin and the number of red blood cells higher than the control. While some groups recorded a decrease in white blood cells (group 3, 4, 5, 6) and the other group recorded an increase in the number (group 2) compared with control group. (Table 6)

Table (4): The effect of feeding rats on the whole sediment produced by tested Bacillus strains on body weights of female albino rats

\begin{tabular}{|c|c|c|c|c|}
\hline Group & $\begin{array}{c}\text { Initial } \\
\text { weight (gm) }\end{array}$ & $\begin{array}{c}\text { Final } \\
\text { weight }(\mathrm{gm})\end{array}$ & $\begin{array}{c}\text { Total } \\
\text { gain }(\mathrm{gm})\end{array}$ & $\begin{array}{c}\text { Daily } \\
\text { gain(gm) }\end{array}$ \\
\hline 1 & $\begin{array}{c}126.8000 \\
\pm 4.575\end{array}$ & $\begin{array}{c}107.2000^{\mathrm{b}} \\
\pm 1.827\end{array}$ & $\begin{array}{c}19.6000^{b} \\
\pm 4.444\end{array}$ & $\begin{array}{c}0.5540^{b} \\
\pm 0.126\end{array}$ \\
\hline 2 & $\begin{array}{c}126.8000 \\
\pm 4.363\end{array}$ & $\begin{array}{c}107.4000^{\mathrm{b}} \\
\pm 4.237\end{array}$ & $\begin{array}{c}19.4000^{\mathrm{b}} \\
\pm 2.249\end{array}$ & $\begin{array}{c}0.5500^{b} \\
\pm 0.063\end{array}$ \\
\hline 3 & $\begin{array}{c}127.4000 \\
\pm 4.456\end{array}$ & $\begin{array}{c}109.0000^{b} \\
\pm 4.461\end{array}$ & $\begin{array}{c}18.4000^{b} \\
\pm 3.155\end{array}$ & $\begin{array}{l}0.5220^{\mathrm{b}} \\
\pm 0.091\end{array}$ \\
\hline 4 & $\begin{array}{c}127.0000 \\
\pm 5.966\end{array}$ & $\begin{array}{c}108.0000^{b} \\
\pm 6.244\end{array}$ & $\begin{array}{c}19.0000^{b} \\
\pm 3.633\end{array}$ & $\begin{array}{c}0.5400^{b} \\
\pm 0.103\end{array}$ \\
\hline 5 & $\begin{array}{c}127.4000 \\
\pm 6.152\end{array}$ & $\begin{array}{c}112.0000^{\mathrm{b}} \\
\pm 6.670\end{array}$ & $\begin{array}{c}15.4000^{b} \\
\pm 2.731\end{array}$ & $\begin{array}{c}0.4360^{b} \\
\pm 0.076\end{array}$ \\
\hline 6 & $\begin{array}{c}127.2000 \\
\pm 4.442\end{array}$ & $\begin{array}{c}140.0000^{\mathrm{a}} \\
\pm 9.612\end{array}$ & $\begin{array}{c}12.8000^{\mathrm{a}} \\
\pm 5.228\end{array}$ & $\begin{array}{c}0.3620^{\mathrm{a}} \\
\pm 0.147^{2}\end{array}$ \\
\hline
\end{tabular}

$1=$ control group $\quad 2$ = group treated with isolate A6 $3=$ group treated with isolate A9

4= group treated with isolate A13 5= group treated with isolate A14 6= group treated with isolate A16

Table (5): The effect of feeding rats on the whole sediment produced by tested Bacillus strains on liver and kidney functions of female albino rats

\begin{tabular}{|c|c|c|c|c|}
\hline Group & $\begin{array}{c}\text { Urea } \\
(\mathbf{m g} / \mathbf{d l})\end{array}$ & $\begin{array}{c}\text { Creatinine } \\
(\mathbf{m g} / \mathbf{d l})\end{array}$ & $\begin{array}{c}\text { ALT(GPT) } \\
(\mathbf{U} / \mathbf{L})\end{array}$ & $\begin{array}{c}\text { AST(GOT) } \\
(\mathbf{U} / \mathbf{L})\end{array}$ \\
\hline 1 & $42.0000 \pm 3.60$ & $0.9167^{\mathrm{ab}} \pm 0.04$ & $22.6667 \pm 1.20$ & $51.3333^{\mathrm{ab}} \pm 0.87$ \\
\hline 2 & $51.3333 \pm 4.05$ & $0.9500^{\mathrm{ab}} \pm 0.07$ & $21.0000 \pm 0.57$ & $41.3333^{\mathrm{b}} \pm 3.37$ \\
\hline 3 & $47.3333 \pm 3.75$ & $0.8167^{\mathrm{ab}} \pm 0.05$ & $23.0000 \pm 4.61$ & $53.000^{\mathrm{ab}} \pm 10.78$ \\
\hline 4 & $47.6667 \pm 3.37$ & $0.7833^{\mathrm{b}} \pm 0.04$ & $21.3333 \pm 3.47$ & $75.0000^{\mathrm{a}} \pm 2.51$ \\
\hline 5 & $50.3333 \pm 5.92$ & $1.0000^{\mathrm{a}} \pm 0.02$ & $23.3333 \pm 0.32$ & $65.6667^{\mathrm{a}} \pm 9.05$ \\
\hline 6 & $47.6667 \pm 2.72$ & $0.933^{\mathrm{ab}} \pm 0.03$ & $25.3333 \pm 2.96$ & $52.3333^{\mathrm{ab}} \pm 9.38$ \\
\hline
\end{tabular}

$1=$ control group

2 = group treated with isolate A6

$3=$ group treated with isolate $\mathrm{A} 9$

Fayoum J. Agric. Res. \& Dev., Vol. 30, No.1, January, 2016 
Table (6): The effect of feeding rats on the whole sediment produced by tested Bacillus strains on blood picture of female albino rats

\begin{tabular}{|c|c|c|c|}
\hline Group & $\begin{array}{c}\text { Hb } \\
(\mathbf{g m} / \mathbf{d l})\end{array}$ & $\begin{array}{c}\text { R.B.C. } \\
(\mathbf{1 0 0 0 0 0 0 / c m 3})\end{array}$ & $\begin{array}{c}\text { W.B.C. } \\
(\mathbf{1 0 0 0 / c m 3})\end{array}$ \\
\hline $\mathbf{1}$ & $10.900 \mathrm{~d} \pm 0.15$ & $3.953 \mathrm{~b} \pm 0.10$ & $6.3500 \mathrm{~b} \pm 633.11$ \\
\hline $\mathbf{2}$ & $12.133 \mathrm{a} \pm 0.23$ & $4.556 \mathrm{a} \pm 0.09$ & $6.7500 \mathrm{~b} \pm 202.07$ \\
\hline $\mathbf{3}$ & $10.933 \mathrm{~d} \pm 0.32$ & $4.490 \mathrm{a} \pm 0.21$ & $5.1167 \mathrm{~cd} \pm 164.14$ \\
\hline $\mathbf{4}$ & $11.833 \mathrm{abc} \pm 0.21$ & $4.423 \mathrm{a} \pm 0.07$ & $4.3000 \mathrm{~d} \pm 189.29$ \\
\hline $\mathbf{5}$ & $11.266 \mathrm{bcd} \pm 0.23$ & $4.236 \mathrm{ab} \pm 0.08$ & $4.6833 \mathrm{~d} \pm 196.92$ \\
\hline $\mathbf{6}$ & $11.000 \mathrm{~cd} \pm 0.40$ & $4.170 \mathrm{ab} \pm 0.13$ & $6.0000 \mathrm{bc} \pm 407.22$ \\
\hline
\end{tabular}

$1=$ control group

$2=$ group treated with isolate A6

$3=$ group treated with isolate A9 $\quad 4=$ group treated with isolate A13

$5=$ group treated with isolate A14 6= group treated with isolate A16

\section{REFERENCES}

Alemu, N. (2014) . Review on concepts in biological control of plant pathogens . J. Biol. Agric.\& Health care., 4(27) : 1-23.

Aparanji, P.; Venkata, R. L. and Krishna, R. M. (2013) . Isolation of potent antibiotic producing Actinomycetes from marine sediments of Andaman and Nicobar Marine Islands. J. Microbiol. Antimicrob., 5(1) : 6-12.

Atlas, R. and Parks, L.C. (1997) . Handbook of Microbiological Media. $2^{\text {ed }}$ ed., CRC press, 1706 pages.

Aruwa, C. E. and Olatope , S. O. A. (2015) . Characterization of Bacillus species from convenience foods with conventional and API Kit method: A comparative analysis. JALSI , 3(1): 42- 48.

Breithaupt, H. (1999) . The new antibiotics. Nat. Biotechnol., 17: 1165-1169.

Ceylan, O.; Okmen, G. and Ugur, A. (2008) . Isolation of soil Streptomyces as source antibiotics active against antibiotic-resistant bacteria. Eur. Asia. J. BioSci., 2: 73-82 .

Doumas, B. T.; Watson, W. A. and Biggs, H. G. (1971) . Albumin standerds and the measurement of serum albumin with bromocresol green. Clin. Chim. Acta, 31:87-96.

Farhana, M. S.; Rahamathbivi, M. and Khairulmazimi, A. (2011) . Effect of carbon sources on bacterial production of metabolites against Fusarium oxysporum and Colletotrichum gloeosporioides Int. J. Agric. Biol., 13: 1- 8.

Fawcett, K. and Soctt, E. (1960) . Enzymatic and colorimetric method for determination of urea in serum, plasma and urine. J. Clin. Path., 13:156-162 .

Fayoum J. Agric. Res. \& Dev., Vol. 30, No.1, January, 2016 
Gornall, A. G.; Bardawill, C. J. and David, M. M. (1948) . Determination of serum protein by means of the biuret reaction, J. Biol. Chem., 177:751-766.

Greenberg, E. P. (2003) - Bacterial communication and group behavior. J. Clin. Invest., 112 : $88-90$.

Jill E. C. (2004). Impact of $16 \mathrm{~S}$ rRNA gene sequence analysis for identification of bacteria on clinical microbiology and infectious diseases . Microbiol. Rev., 17(4) : 840 - 862 .

Kawaguchi, M.; Nonaka, K.; Masuma, R. and Tomoda, H. (2013) . New method for isolating antibiotic-producing fungi . J. Antibiotics, 66 :17- 21.

Kumar, N.; Siji, J. V.; Ramya, R.; Nambisan, B. and Mohandasd, C. (2012) - Improvement of antimicrobial activity of compounds produced by Bacillus sp. Associated with a Rahabditid sp . (Entomopa thogenic nematode) by changing carbon and nitrogen source in fermentation media. JMBFS., 1 (6) :1424 - 1438 .

Kuta, F. A.; Nimzing, L. and Orka'A, P. Y. (2009) . Screening of Bacillus species with potentials of antibiotics production. Appl. Med. Informatics., 24(1-2) : 42 - 46 .

Liasi, S. A.; Azmi, T. I.; Hassan, M. D.; Shuhaimi, M.; Rosfarizan, M. and Ariff, A. B. (2009) . Antimicrobial activity and antibiotic sensitivity of three isolates of lactic acid bacteria from fermented fish product, Budu . Mal. J. Microbiol., 5(1) : 33 - 37.

Malanicheva, I. A.; Kozlov, D. G.; Sumarukova, I. G.; Efremenkova, O. V.; Zenkova,V. A.; Katrukha, G. S.; Reznikova, M. I.; Tarasova, O. D.; Sineokii, S. P. and Registan, G. I. (2012) . Antimicrobial Activity of Bacillus megaterium Strains. Microbiol. , 81(2): $178-185$.

Moshafi, M.; Forootanfar, H.; Ameri, A.; Shakibaie, M.; DehghanNoudehig and Mojdeh, R. (2011) . Antimicrobial activity of Bacillus sp. Strain fasi isolated from soil . Pak. J. Pharm.Sci., 24(3) : 269 - 275.

Ogunmwonyi , I. N. H. (2010) . Assessment Of Antibiotic Production by Some Marine Streptomyces Isolated From The Nahoon Beach . Msc. Thesis University of Fort Hare Faculty of Science and Agriculture. Alice, South Africa .

Reitman, S. and Frankel, S. (1957) - A colorimetric method for the determination of serum glutamic oxaloacetic and glutamic pyruvic transaminases . Amer. J. Clin. Pathol., 28:56 - 63.

Fayoum J. Agric. Res. \& Dev., Vol. 30, No.1, January, 2016 
PRODUCTION OF ANTIMICROBIALNTS.............................13

Sarker, D.; Roy, N.; and Yeasmin, T. (2010) . Isolation and antibiotic sensitivity of Bacillus thuringinesis strain from dump soil . Mal. J. Microbiol., 6(2) : 127 - 132 .

Tabbene, O.; Kalai, L.; Slimene, I. B.; Karkouch, I.; Elkahoui, S.; Gharbi, A.; Cosette, P.; Mangoni, M. L.; Jouenne, T. and Limam, F. (2011) . Anti-Candida effect of bacillomycin D-like lipopeptides from Bacillus subtilis B38. FEMS Microbiol. Lett., 316 :108 - 114

$$
\text { انتاج بعض المواد المضادة للميكروبات من بعض عزلات الباسيلس }
$$

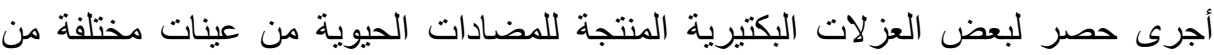

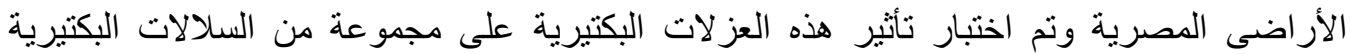

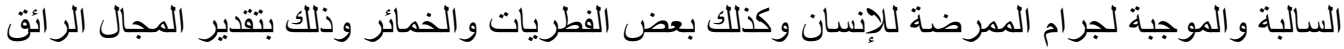

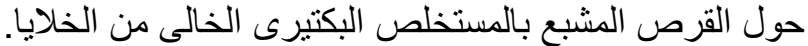

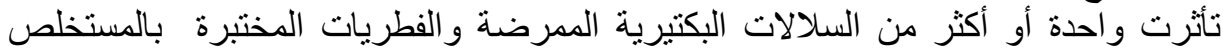

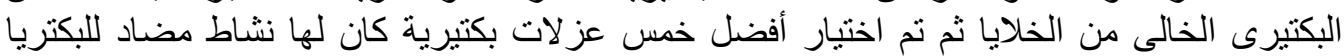

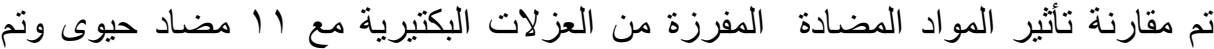

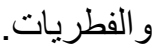
تعريف أقوى العزلات البكتيرية بنظام API 50 CHB والذى أوضح ألنات هذه العز لات هى Bacillus Bacillus subtilis و Bacillus amyloliquefaciens glicheniformis كذلك تم تعريف أقوى عزلتين لهما تأثئر مضاد للميكروبات بنظام 16sr RNA و الذى اوضحت نتائجه أن العزلات هى تهى B. methylotrophicus \& B. sonorensis

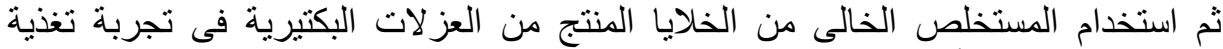

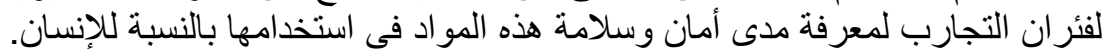

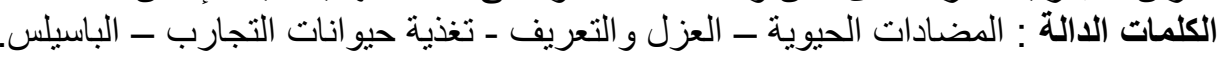

Fayoum J. Agric. Res. \& Dev., Vol. 30, No.1, January, 2016 
Fayoum J. Agric. Res. \& Dev., Vol. 30, No.1, January, 2016 
PRODUCTION OF ANTIMICROBIALNTS............................15

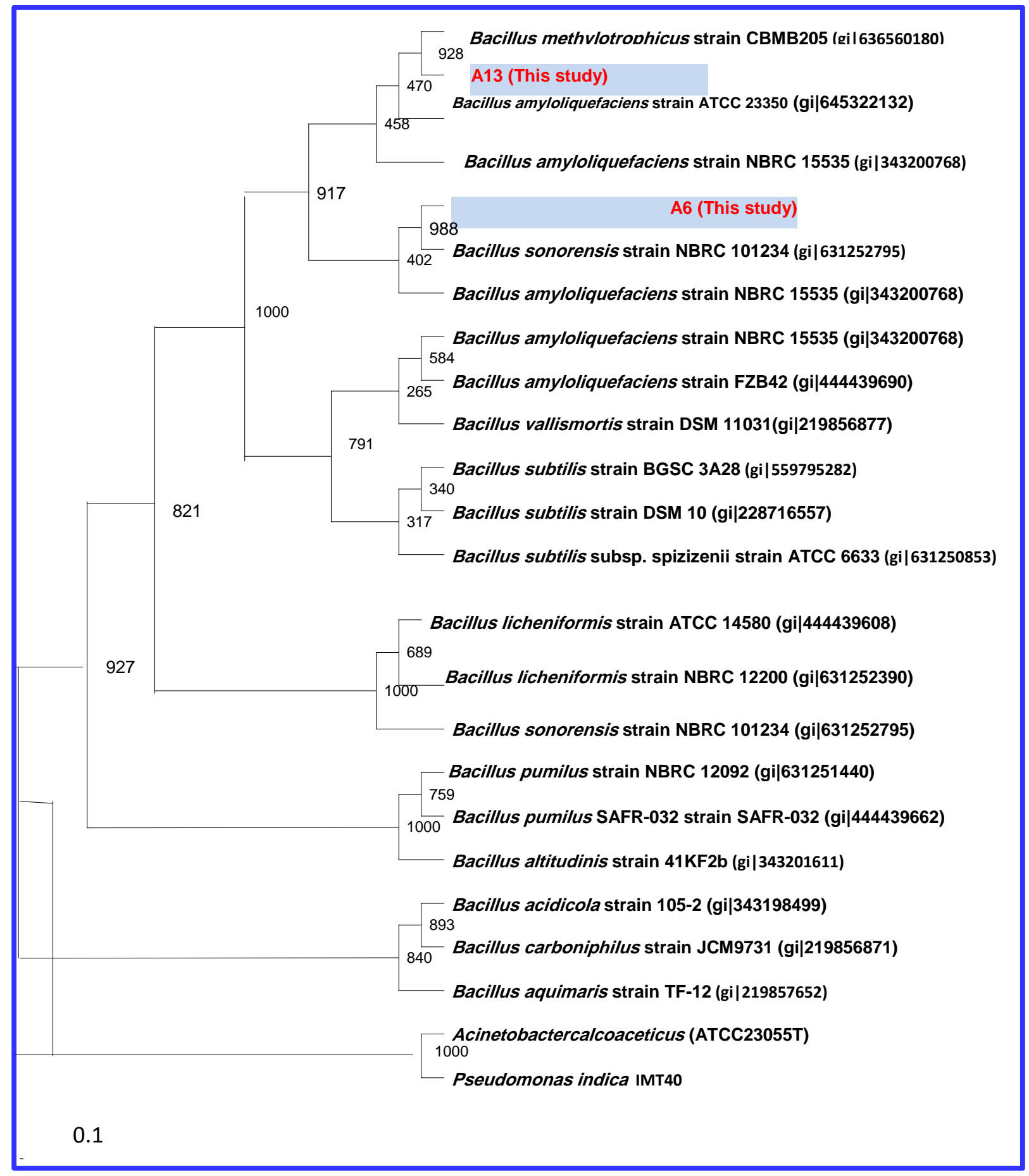

igure (1): Neighbor joining tree showing the estimated phylogenetic relationships of A6 and A13 and nearest members of Bacillus strains. Bootstrap values are shown as - percentages of 1000 replicates. Bar: $0.1 \%$ sequence divergence. Fayoum J. Agric. Res. \& Dev., Vol. 30, No.1, January, 2016 